\title{
Centipedes, millipedes, terrestrial isopods and their relationships to physical and chemical properties of forest soils
}

\author{
Emanuel Kula \& Martin Lazorík
}

Kula, E. \& Lazorík, M. 2016: Centipedes, millipedes, terrestrial isopods and their relationships to physical and chemical properties of forest soils. - Entomol. Fennica 27: 33-51.

The quality of soil environment in forest ecosystems of mountain zones was characterised by skeleton content and particle size as well as soil moisture and chemistry and used for deepening the knowledge of ecological requirements of centipedes, millipedes and terrestrial isopods. Soil skeleton and size of the particles were significant environmental factors, with Lithobius austriacus, Lithobius erythrocephalus and Lithobius nodulipes preferring stony soils. The isopods Ligidium hypnorum and Hyloniscus riparius were closely bound to heavy soils with a high clay content, which was related to increased soil moisture and indication of waterlogged soils. Soil reaction $(\mathrm{pH} / \mathrm{KCl})$ was less associated with the occurrence of the studied invertebrates. The soils with higher skeleton content and a favourable moisture regime containing more $\mathrm{Ca}^{2+}$ and $\mathrm{Mg}^{2+}$ were more attractive to some centipedes (Strigamia acuminata, Lithobius microps) and isopods (Trachelipus ratzeburgii, Oniscus asellus, Porcellio scaber).

E. Kula \& M. Lazorik, Department of Forest Protection and Game Management, Faculty of Forestry and Wood Technology Zemědèlská 3, CZ-61300 Brno; Email:kula@mendelu.cz,lazorik.martin@atlas.sk

Received 30 June 2015, accepted 26 December 2015

\section{Introduction}

Knowledge of interactions between the soil environment and soil fauna forms an important background for objective assessment of other factors affecting the complex of relationships such as impacts of climate change (Briones et al. 1997, Dollery et al. 2006, David \& Handa 2010), changes in species composition of woody plants in native stands (Schreiner et al. 2012), differences in the setting of ravines (Schlaghamerský et al. 2014) or reforestation of grasslands (Carpenter et al. 2012). Earlier observations also suggest the possibility of occurrence of different soil in- vertebrates based on different characteristics of soil environment (Scheu \& Schulz 1996).

To understand the differences in behavior of invertebrates, it is necessary to know the basic characteristics of soils in forest ecosystems. Soil is based on the soil-forming substrate (Bedrna 1977, Němeček et al. 1990), which affects through its quality of the edaphon (Mařan \& Káš 1948) that consequently influences the ongoing soil-forming processes. Soil chemistry affects weathering of the parent rock, and thus also particle size and skeleton content. Soil texture is the most stable characteristic of the soil environment, influencing to a critical extent the porosity, air 
and water regimes, infiltration and humus formation processes and fertility of soil (Brady \& Weil 2008). Knowledge of soil chemistry is a precondition of the possibility to study the manifestations of soil invertebrates.

Diplopoda and Lumbricidae play an important role in transformations of the soil environment of the ecosystem (Schaefer 1991) and fulfil the criterion as suitable individual invertebrates for the bioindication of the soil quality and in this context of global climate change (Blackburn et al. 2002, Tuf \& Tufová 2008, Dunger \& Voigtländer 2009). Soil properties and their influence on the distribution and presence of the species of the orders Lithobiomorpha and Geophilomorpha were studied by Scheu \& Poser (1996), Blackburn et al. (2002) and Jabin (2008). Blackburn et al. (2002) and Jabin (2008) suggested that assessing the soil environment using solely the chemical composition of the soil may not estimate some of the soil properties correctly. The results so far show only a minor importance of soil reaction for Lithobiomorpha, in contrast to soil moisture. Some partial results defining the relationship of soil environment and individual centipede, millipede and terrestrial isopod species have been published but no conclusive data exists so far.

Faunistic data on centipedes, millipedes and terrestrial isopods of the Moravian-Silesian Beskyds were published by Kula et al. (2011). This study aimed at assessing the preferences of soilepigeic centipedes, millipedes and terrestrial isopods along the gradients of chemical and physical properties of soil. The presence of centipedes, millipedes and terrestrial isopods was monitored using pitfall traps in 2007-2012 over each year's growing season.

\section{Materials and methods}

\subsection{Study area}

The sites forming the monitoring grid (38 plots, Fig. 1) encompass a broad spectrum of mesoclimatic conditions of the massifs of Smrk and Kněhyně mountains of the Moravian-Silesian Beskyds (the Czech Republic). They are situated within the altitudinal range of $540-1,220 \mathrm{~m}$ above the sea level. The climate is characterised by average annual precipitation of $690-934 \mathrm{~mm}$ and average annual temperature of $2.6{ }^{\circ} \mathrm{C}$ with the minimum in January $\left(-6.1^{\circ} \mathrm{C}\right)$ and maximum in July $\left(11.7^{\circ} \mathrm{C}\right)$, the absolute minimum and maximum temperatures being $-30.9^{\circ} \mathrm{C}$ and $29.5^{\circ} \mathrm{C}$, respectively (weather station: Lysá hora, $1,323 \mathrm{~m}$ a. s. 1.). For other details, see Kula et al. (2011).

The network of research plots covers an area of $58 \mathrm{~km}^{2}$, where the distances between the most remote locations are $8.45 \mathrm{~km}$ in east-west direction and $6.85 \mathrm{~km}$ in north-south direction (Fig. 1). The average distance between the plots is 1.2 $\mathrm{km}$. All study sites are located on soils covered with forests that have been used for forestry for a long time. Close-to-natural forest management is realised in the studied territory.

\subsection{Collecting the invertebrates}

To capture epigeic fauna, five pitfall traps (glass round-neck-shaped jars with the diameter of 93 $\mathrm{mm}$ and overall height of $263 \mathrm{~mm}$ ), each with $4,000 \mathrm{ml}$ of formaline ( $4 \%$ formaldehyde) as a fixative solution were set on each study site. The traps were sheltered with roofs and situated along a transect with $10 \mathrm{~m}$ spacing. The traps were inspected every six weeks from 1 April to 30 October in 2007-2012. Mixed samples were formed by pooling the material from all the five traps at each site on each of the inspection dates and were kept in 75\% ethanol. In the years 2007-2009, the invertebrates were determined under the direct supervision of RNDr. \& Mgr. Ivan Hadrian Tuf, Ph.D. and Mgr. Jana Tufová, Ph.D. (Faculty of Science, Palacký University Olomouc) while the material from the years 2010-2013 was determined by one of the authors (M. L.).

\subsection{Soil sampling}

A rectangular soil pit was excavated at each site (August 2009) allowing us to describe the soil profile, determine the depth of the individual horizons and carry out the chemical analysis in line with the Taxonomic Soil Classification System of the Czech Republic (Němeček et al. 2001). The pit must be deep enough $(70-120 \mathrm{~cm})$ to uncover all the soil horizons. The width $\times$ length was $70 \times$ 
Fig. 1. Locations of study sites in the mountains Beskids massifs in the Spruce and Kněhyně and along the river Čeladenka. A ring beside the number represents the location of the site. Shown is an area of $58 \mathrm{~km}^{2}$.

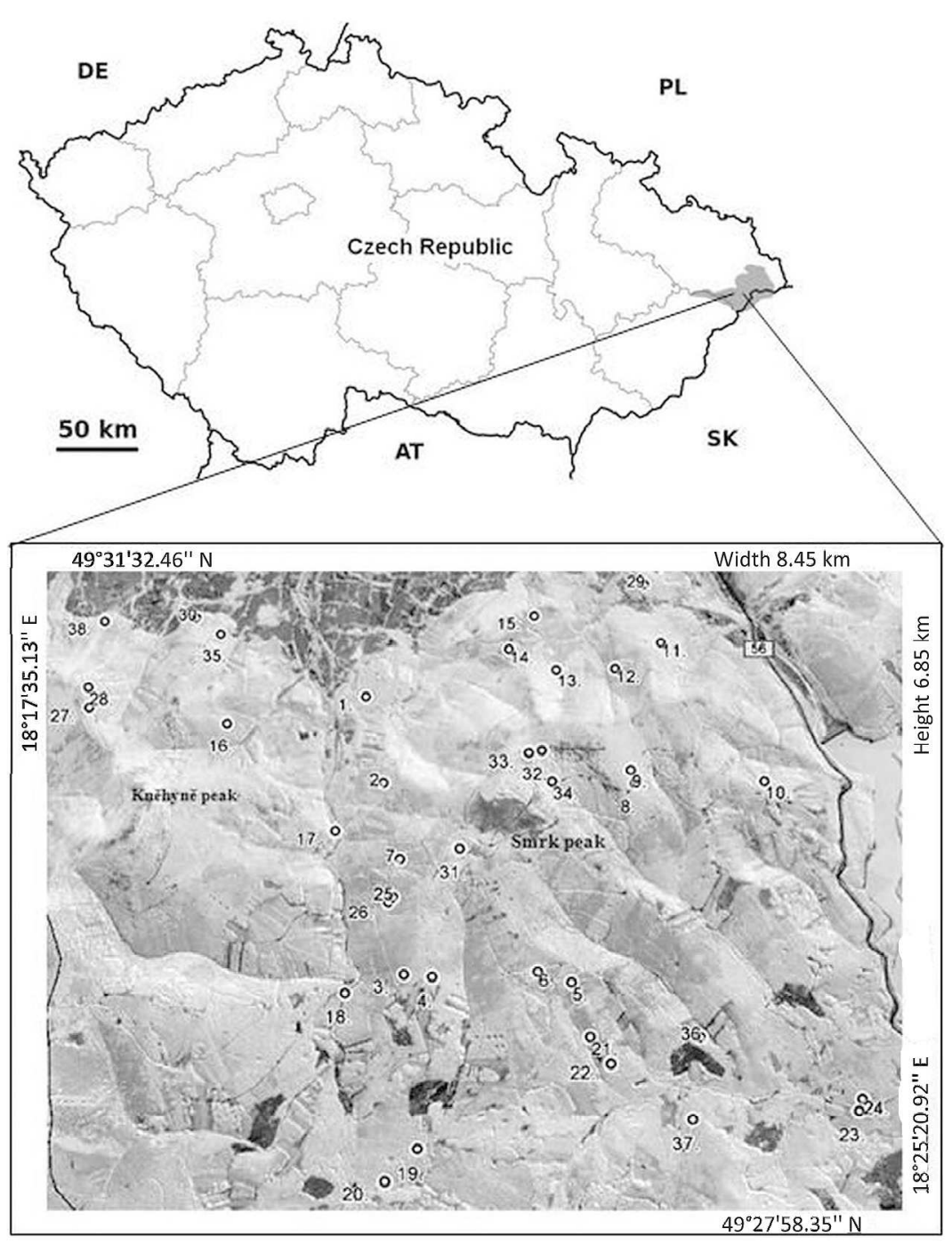

$100 \mathrm{~cm}$, The excavation of the soil pits was performed manually with spades, shovels and pickaxes. In flat terrains, the back side of the soil pit was oriented to the north. On the slopes, the backside of the pit must be oriented against the slope, which means that the longitudinal axis of the pit was perpendicular to the contour. The face, back side and the two side edges were vertical (perpendicular to the ground of the pit).

To determine the physical properties and characteristics of water and air regime of the soil, we collected undisturbed soil samples in the socalled Kopecky cylinders. The cylinders are made of stainless steel, capacity of $100 \mathrm{~cm}^{3}$ and the height of $5 \mathrm{~cm}$ (Čurlík \& Šurina 1998, Jandák 2003).

\subsection{Skeleton content and particle size}

Skeleton content was defined as the weight percentage of solid particles larger than $2 \mathrm{~mm}$. Soil samples were taken from each horizon of the soil pit, the sample specific weight being $500 \mathrm{~g}$. Each sample was washed through sieves with mesh sizes gradually decreasing to $2 \mathrm{~mm}$. The skeleton sample was then dried at $105^{\circ} \mathrm{C}$ and weighed. The weight percentage of the skeleton was determined as the proportion of dry weight of the skeleton and weight of a $500 \mathrm{~g}$ sample converted to dry matter under ČSN ISO 11464 (1998).

Particle size was determined by the standard sedimentation method where each of the fineearth fractions was converted to the percentage of 
Table 1. Characterization of study sites. Site numbers refer to those in Fig. 1.

A. Type of top soil layers (horizons $A$ and B) with ionic concentrations $\left(\mathrm{cmol}^{+} / \mathrm{kg}\right)$ and $\mathrm{pH}$.

\begin{tabular}{|c|c|c|c|c|c|c|c|c|}
\hline Site & Soil type & $\mathrm{Al}^{2+}$ & $\mathrm{H}^{+}$ & $\mathrm{Ca}^{2+}$ & $\mathrm{Mg}^{2+}$ & $\mathrm{K}^{+}$ & $\mathrm{Na}^{2+}$ & $\mathrm{pH} / \mathrm{KCl}$ \\
\hline 1 & Leptosols & 12.40 & 7.26 & 2.48 & 0.81 & 1.17 & 0.23 & 2.80 \\
\hline 2 & Leptosols & 2.61 & 3.82 & 11.66 & 2.27 & 1.42 & 0.10 & 3.50 \\
\hline 3 & entic Podzols & 2.63 & 3.90 & 11.15 & 1.94 & 1.72 & 0.20 & 3.47 \\
\hline 4 & haplic Podzols & 7.25 & 4.85 & 3.82 & 0.84 & 1.04 & 0.15 & 3.02 \\
\hline 5 & haplic Podzols & 2.09 & 5.02 & 8.11 & 1.53 & 1.87 & 0.09 & 3.32 \\
\hline 6 & Cambisols & 1.11 & 1.04 & 24.03 & 3.08 & 1.50 & 0.22 & 4.29 \\
\hline 7 & Leptosols & 1.64 & 2.24 & 18.16 & 2.46 & 1.46 & 0.10 & 3.75 \\
\hline 8 & haplic Podzols & 7.99 & 8.59 & 4.64 & 0.75 & 0.86 & 0.18 & 2.99 \\
\hline 9 & Cambisols & 10.80 & 2.18 & 1.35 & 0.43 & 0.52 & 0.09 & 2.74 \\
\hline 10 & Leptosols & 11.12 & 2.97 & 4.62 & 0.78 & 0.72 & 0.12 & 3.15 \\
\hline 11 & Leptosols & 9.44 & 5.20 & 4.28 & 0.95 & 0.87 & 0.21 & 2.95 \\
\hline 12 & entic Podzols & 7.40 & 0.96 & 5.04 & 0.71 & 0.65 & 0.08 & 3.31 \\
\hline 13 & Leptosols & 6.98 & 2.22 & 1.23 & 0.49 & 0.49 & 0.08 & 2.78 \\
\hline 14 & Cambisols & 10.08 & 1.30 & 4.47 & 0.91 & 0.93 & 0.10 & 3.41 \\
\hline 15 & Leptosols & 1.09 & 0.47 & 38.88 & 14.71 & 1.04 & 0.14 & 4.43 \\
\hline 16 & Leptosols & 6.22 & 6.10 & 7.89 & 1.02 & 1.15 & 0.09 & 3.11 \\
\hline 17 & Fluvisols & 9.24 & 4.11 & 4.45 & 0.91 & 1.08 & 0.10 & 3.07 \\
\hline 18 & Fluvisols & 13.33 & 3.98 & 2.17 & 1.15 & 1.16 & 0.09 & 3.13 \\
\hline 19 & Gleysols & 11.89 & 8.22 & 3.67 & 2.05 & 1.88 & 0.55 & 3.03 \\
\hline 20 & Histosols & 0.73 & 0.11 & 50.66 & 4.03 & 0.19 & 0.35 & 5.01 \\
\hline 21 & Cambisols & 2.47 & 4.44 & 17.01 & 2.34 & 2.29 & 0.12 & 3.95 \\
\hline 22 & Cambisols & 7.53 & 11.19 & 4.48 & 0.95 & 1.11 & 0.12 & 2.97 \\
\hline 23 & Histosols & 7.60 & 1.36 & 13.27 & 4.10 & 0.17 & 0.18 & 3.77 \\
\hline 24 & Stagnosols & 23.49 & 3.47 & 3.05 & 1.44 & 1.70 & 0.22 & 3.34 \\
\hline 25 & entic Podzols & 1.76 & 1.10 & 18.63 & 2.59 & 1.14 & 0.15 & 4.11 \\
\hline 26 & Leptosols & 10.70 & 4.41 & 9.50 & 2.26 & 0.99 & 0.18 & 3.00 \\
\hline 27 & Cambisols & 7.86 & 1.43 & 4.88 & 1.02 & 0.81 & 0.07 & 3.18 \\
\hline 28 & Cambisols & 9.56 & 1.74 & 6.28 & 2.02 & 0.96 & 0.09 & 3.29 \\
\hline 29 & Leptosols & 8.00 & 4.59 & 9.01 & 1.08 & 0.99 & 0.09 & 3.05 \\
\hline 30 & Cambisols & 9.73 & 5.19 & 6.93 & 1.14 & 1.01 & 0.09 & 2.98 \\
\hline 31 & Cambisols & 12.86 & 2.98 & 2.55 & 0.82 & 0.75 & 0.11 & 2.74 \\
\hline 32 & Leptosols & 7.72 & 9.03 & 5.16 & 1.67 & 2.75 & 0.18 & 3.14 \\
\hline 33 & haplic Podzols & 12.61 & 7.13 & 3.17 & 1.09 & 1.01 & 0.17 & 2.79 \\
\hline 34 & haplic Podzols & 7.36 & 5.52 & 5.26 & 1.04 & 1.45 & 0.17 & 3.00 \\
\hline 35 & Cambisols & 1.37 & 1.72 & 16.67 & 2.36 & 1.16 & 0.08 & 4.04 \\
\hline 36 & Cambisols & 10.41 & 4.69 & 3.41 & 1.21 & 1.39 & 0.14 & 3.09 \\
\hline 37 & Cambisols & 9.66 & 5.27 & 5.27 & 1.20 & 1.14 & 0.10 & 2.87 \\
\hline 38 & haplic Podzols & 8.01 & 7.92 & 5.62 & 1.15 & 1.20 & 0.07 & 3.12 \\
\hline
\end{tabular}

B. Soil moisture (in soil horizons A and B) (\%) and composition (\%) as well as altitude (m) and main tree species (S - Norway spruce; B - beech).

\begin{tabular}{|c|c|c|c|c|c|c|c|c|}
\hline \multirow[t]{2}{*}{ Site } & \multicolumn{2}{|c|}{ Moisture } & \multicolumn{4}{|c|}{ Composition" } & \multirow[t]{2}{*}{ Alt. } & \multirow[t]{2}{*}{ Trees } \\
\hline & $\mathrm{HA}$ & HB & Clay & f.dust & g.dust & f.sand & & \\
\hline 1 & - & - & 6.5 & 7.4 & 26.1 & 60.0 & 600 & $S$ \\
\hline 2 & 28.45 & 28.77 & 1.0 & 11.4 & 26.4 & 61.2 & 815 & B \\
\hline 3 & 29.43 & 31.26 & 1.9 & 7.5 & 33.7 & 56.9 & 880 & B \\
\hline 4 & 29.09 & 27.48 & 3.6 & 6.9 & 39.1 & 50.4 & 890 & $S$ \\
\hline 5 & 25.96 & 31.08 & 16.7 & 15.5 & 26.8 & 41.0 & 850 & $B$ \\
\hline 6 & 29.57 & 39.15 & 0.0 & 9.2 & 41.7 & 49.1 & 915 & B \\
\hline 7 & - & - & 1.5 & 10.1 & 21.3 & 67.1 & 855 & $B$ \\
\hline 8 & - & - & 2.2 & 5.8 & 33.7 & 58.3 & 1,010 & $S$ \\
\hline 9 & 40.87 & 37.91 & 2.4 & 11.3 & 22.3 & 64.0 & 1,045 & $S$ \\
\hline 10 & 19.87 & 23.36 & 13.1 & 17.1 & 26.1 & 43.8 & 845 & $S$ \\
\hline
\end{tabular}


Table 1, continued

\begin{tabular}{|c|c|c|c|c|c|c|c|c|}
\hline 11 & - & - & 6.0 & 11.9 & 22.8 & 59.3 & 840 & $S$ \\
\hline 12 & 32.98 & 32.02 & 0.8 & 9.4 & 29.3 & 60.6 & 835 & B \\
\hline 13 & 29.86 & 35.47 & 0.0 & 9.1 & 16.6 & 74.3 & 850 & $S$ \\
\hline 14 & 24.36 & 30.14 & 11.0 & 25.3 & 39.8 & 23.9 & 830 & $S$ \\
\hline 15 & - & - & 1.9 & 4.7 & 15.3 & 78.1 & 780 & $S$ \\
\hline 16 & 20.86 & 15.30 & 20.0 & 22.2 & 36.4 & 21.3 & 785 & $S$ \\
\hline 17 & - & - & 12.2 & 8.2 & 16.6 & 62.9 & 560 & $S$ \\
\hline 18 & 29.87 & 24.34 & 7.9 & 8.0 & 15.3 & 68.8 & 610 & $S$ \\
\hline 19 & 42.53 & 49.41 & 22.0 & 21.6 & 35.1 & 21.4 & 680 & $S$ \\
\hline 20 & 48.05 & 49.34 & - & - & - & - & 660 & $S$ \\
\hline 21 & 30.77 & 30.57 & 18.6 & 15.5 & 24.5 & 41.1 & 730 & B \\
\hline 22 & - & - & 15.2 & 17.4 & 31.4 & 36.0 & 695 & $S$ \\
\hline 23 & 49.85 & 48.69 & 27.1 & 17.0 & 20.1 & 35.8 & 530 & $S$ \\
\hline 24 & 38.17 & 39.54 & 1.0 & 13.9 & 46.4 & 39.7 & 540 & $S$ \\
\hline 25 & 24.75 & 25.78 & 0.4 & 8.4 & 32.1 & 59.1 & 870 & B \\
\hline 26 & 29.52 & 24.59 & - & - & - & - & 825 & $S$ \\
\hline 27 & 33.52 & 31.93 & 8.9 & 18.4 & 28.4 & 44.3 & 1,015 & B \\
\hline 28 & - & - & 11.2 & 13.2 & 37.4 & 38.2 & 1,025 & B \\
\hline 29 & 17.40 & 21.9 & 3.5 & 12.8 & 25.5 & 58.3 & 620 & $\bar{S}$ \\
\hline 30 & - & - & 4.9 & 9.9 & 23.1 & 62.0 & 630 & $S$ \\
\hline 31 & 27.10 & 29.32 & 1.5 & 10.0 & 30.1 & 58.3 & 1,100 & $S$ \\
\hline 32 & - & - & 1.3 & 8.3 & 12.9 & 77.5 & 1,190 & $S$ \\
\hline 33 & 33.72 & 34.32 & 0.4 & 10.1 & 16.8 & 72.7 & 1,220 & $S$ \\
\hline 34 & 33.06 & 34.06 & 11.6 & 11.5 & 16.6 & 60.3 & 1,100 & $S$ \\
\hline 35 & 29.03 & 25.49 & 12.7 & 30.6 & 37.8 & 18.9 & 635 & B \\
\hline 36 & 26.61 & 23.11 & 16.6 & 19.1 & 33.1 & 31.1 & 620 & $S$ \\
\hline 37 & 22.67 & 21.74 & 2.6 & 11.1 & 15.9 & 70.4 & 645 & $S$ \\
\hline 38 & 29.76 & 26.98 & 20.2 & 17.2 & 23.1 & 39.5 & 635 & $S$ \\
\hline
\end{tabular}

\# f.dust: fine dust, g.dust: gross dust, f.sand: fine sand.

the total weight of each sample collected. The classification scale by Casagrande (1948) was used for the fractions:

- Clay $<0.002 \mathrm{~mm}$,

- Fine dust (f.dust) $0.002-0.01 \mathrm{~mm}$,

- Gross dust (g.dust) 0.01-0.05 mm,

- Fine sand (f.sand) 0.05-2 mm.

\subsection{Soil moisture}

Soil moisture was determined by measuring soil resistivity at hourly intervals using the Virrib sensor that was attached to the Virrib data logger (Amet Velké Bílovice). The Virrib Sensor has two concentric rings of stainless steel, connected to the sensor body. The sensor body is a mechanically fixed mass, which prevents water from penetrating to the electronic part. The diameter of the outer ring is $280 \mathrm{~mm}$ and its measuring capacity is from 15 to 201 of soil. The function of the sensor is based on the principle of electromagnetic wave propagation in the environment. The power supply of the sensor is $12-20 \mathrm{~V}$ from an external source. The sensor operates on the principle of the current loop, where an electric pulse is sent between the circles of the sensor at set intervals. Consequently, the size of the output current is proportional to the percentage of moisture. Volumetric soil moisture is the water content of total soil volume. At each study site, two Virrib sensors were installed in the middle of the transect from where the invertebrate samples were collected (by the third pitfall trap); one sensor was placed in the centre of the top layer of the A horizon and another one in the centre of the organomineral layer of the $\mathrm{B}$ horizon. The measuring range was $5-50 \%$ of volumetric soil moisture. The data were recorded from April 2008 to October 2009.

To classify the levels of soil moisture, the scale by Kutílek (1971) was used:

- Dry (DryHA, DryHB) $<25 \%$, 
- Moist (MoistHA, MoistHB) 25.1-35\%,

- Wet (WetHA, WetHB) 35.1-45\%,

- Slush (SlushHA, SlushHB) 45.1-50\%, wherein the target soil layer is identified in the humus horizon (HA) and in the organo-mineral horizon $(\mathrm{HB})$.

\subsection{Exchangeable soil reaction}

Exchangeable soil reaction depends on the activity of aqueous hydrogen ions bound to soil colloidal complex (solid part of the soil). The activity of hydrogen ions causes alkaline reaction of soil. Soil reaction strongly influences the process of formation and development of soil. Exchangeable soil reaction was measured for each soil pit and its horizons under laboratory conditions by potentiometer in a suspension formed of a $1 \mathrm{M}$ of $\mathrm{KCl}$ solution (2.5 parts) and soil (1 part) within one hour (Zbíral 2002).

\subsection{Chemical properties of soil}

A subsample of each soil sample was taken from each soil horizon. After removal of undecomposed parts of plant and coarse skeleton, the sample was turned into a fine fraction by crushing. The sample was sifted using a screen of the mesh size of $2 \mathrm{~mm}$ and analysed as described below.

\subsubsection{Exchangeable elements (e)}

The chemical analysis determined the concentration of exchangeable protons $\mathrm{H}^{+}$and $\mathrm{Al}^{-}$(by titration potentiometer) and exchangeable elements $\mathrm{Ca}^{2+}, \mathrm{Mg}^{2+}, \mathrm{K}^{+}$and $\mathrm{Na}^{+}$in the humus horizon (HA and $\mathrm{HB}$ combined) after extraction by the method according to Göhler (Soukup et al. 1987) and in the organo-mineral horizon (HA) after extraction by the method according to Mehlich III (Mehlich 1984, Zbíral 1997) under ČSN ISO 11260 (1998).

The exchangeable elements present in the soil environment bound in colloids are easily accessible to plants and were included as a part of the analyses in this study: exchangeable hydrogen proton $(\mathrm{eH})$, exchangeable calcium (eCA), mag- nesium $(\mathrm{eMg})$, potassium $(\mathrm{eK})$ and sodium $(\mathrm{eNa})$ $\left(\mathrm{cmol}^{+} \times \mathrm{kg}^{-1}\right)$.

\subsubsection{Accessible elements ( $p a)$}

Accessible elements form a group of elements soluble in soil solution, immediately surrounding the roots of plants and bodies of animals. They were determined using the Mehlich III method by extracting the leachate from the soil solution (Mehlich 1984). The group includes of accessible phosphorus oxide ( $\mathrm{paP}$ ), accessible potassium oxide (paK), accessible calcium oxide ( $\mathrm{paCa}$ ) and accessible magnesium oxide $(\mathrm{paMg})\left(\mathrm{mg} \times \mathrm{kg}^{-1}\right)$.

\subsubsection{Bound elements $(t)$}

Bound elements are engaged in chemical bonds and they are hard to be accessed by plants and animals. Their release often depends on the weathering process. The content of these elements was determined by the technique of decomposition in $20 \% \mathrm{HCl}$. The group consists of bound iron oxide (tFe), bound aluminium oxide (tAl), bound manganese oxide ( $\mathrm{tMn}$ ), and the content of oxidised forms of calcium $(\mathrm{tCa})$, bound magnesium oxide $(\mathrm{tMg})$, bound potassium oxide $(\mathrm{tK})$ and bound phosphorus oxide $(\mathrm{tP})\left(\mathrm{mg} \times \mathrm{kg}^{-1}\right)$.

\subsection{Data analysis}

The correlations of environmental variables were analysed along with the occurrence of invertebrates using redundancy analysis (RDA) or canonical correspondence analysis (CCA). A suitable analysis was selected by Detrended Canonical Analysis (DCA). The DCA results of eigenvalues formed the basis for determining the use of RDA or CCA. If all canonical eigenvalues in DCA are less than 3.0 , it is more appropriate to use RDA, while if they are over 3.0, CCA is more appropriate. RDA is closely linked to Multivariate linear regression, and is used in cases where a linear relationship is expected whereas CCA allows nonlinearity. Distances split-plot and permutation of the Monte Carlo test (999 permutations) for CANOCO were applied in the CCA or RDA analyses. Data were $\log (\mathrm{y}+1)$ transformed and rare species were down 
Table 2. Mean and total number of specimens of different species of Diplopoda, Chilopoda and terrestrial Isopoda in 38 study sites, and number of sites with specimens.

\begin{tabular}{|c|c|c|c|c|}
\hline Species & Abbrev. & Mean no. & Total no. & No. of sites \\
\hline \multicolumn{5}{|l|}{ Chilopoda } \\
\hline Cryptops parisi Brölemann, 1920 & C_par. & 2.1 & 44 & 21 \\
\hline Goephilus flavus (DeGeer, 1778) & G_fla. & 1.5 & 32 & 21 \\
\hline Geophilus insculptus Attems, 1895 & G_inst. & 1.0 & 1 & 1 \\
\hline Lithobius austriacus Verhoeff, 1937 & L_aus. & 13.7 & 123 & 9 \\
\hline Lithobius biunguiculatus Loksa, 1947 & L_biu. & 1.0 & 1 & 1 \\
\hline Lithobius borealis Meinert, 1868 & L_bor. & 1.7 & 7 & 4 \\
\hline Lithobius burzenlandicus Verhoeff, 1934 & L_bur. & 1.0 & 2 & 2 \\
\hline Lithobius cyrtopus Latzel, 1880 & $\mathrm{~L}_{-}$cyr. & 19.6 & 747 & 38 \\
\hline Lithobius erythrocephalus C.L.Koch, 1847 & L_eryt. & 50.8 & 1,931 & 38 \\
\hline Lithobius forficatus Linnaeus, 1758 & L_for. & 111.0 & 4,219 & 38 \\
\hline Lithobius micropodus (Matic, 1868) & L_mpod. & 2.0 & 6 & 3 \\
\hline Lithobius microps Meinert, 1868 & L_mic. & 5.6 & 186 & 33 \\
\hline Lithobius mutabilis L.Koch, 1862 & L-mut. & 99.0 & 3,761 & 38 \\
\hline Lithobius nodulipes Latzel, 1880 & L_nod. & 6.1 & 158 & 26 \\
\hline Lithobius pelidnus Haase, 1880 & L_pel. & 2.0 & 28 & 14 \\
\hline Lithobius piceus L.Koch, 1862 & L_pic. & 1.0 & 1 & 1 \\
\hline Lithobius tenebrosus Meinert, 1872 & L_ten. & 2.8 & 54 & 19 \\
\hline Strigamia acuminata (Leach, 1814) & S_acu. & 5.9 & 170 & 29 \\
\hline Strigamia transsilvanica (Verhoeff, 1928) & S_tran. & 1.2 & 5 & 4 \\
\hline \multicolumn{5}{|l|}{ Diplopoda } \\
\hline Brachydesmus superus Latzel, 1884 & Br_sup. & 1.3 & 8 & 6 \\
\hline Brachyiulus bagnalli (Curtis, 1845) & $\mathrm{Br}$ bag. & 1.4 & 7 & 5 \\
\hline Cylindroiulus nitidus (Verhoeff, 1891) & Cy_nit. & 1.5 & 6 & 4 \\
\hline Glomeris connexa C.L.Koch, 1847 & Gl_con. & 25.3 & 785 & 31 \\
\hline Glomeris hexasticha Brandt, 1833 & Gl_hex. & 7.3 & 51 & 7 \\
\hline Glomeris pustulata Latreille, 1804 & Gl-pus. & 1.0 & 1 & 1 \\
\hline Haasea flavescens (Latzel, 1884) & Häfla. & 6.0 & 12 & 2 \\
\hline Julus scandinavius Latzel, 1884 & Ju_scan. & 2.8 & 67 & 24 \\
\hline Julus terrestris Linnaeus, 1761 & Ju_terr. & 1.7 & 5 & 3 \\
\hline Leptoilus trilobatus (Verhoeff, 1894) & Le_tri. & 8.6 & 318 & 37 \\
\hline Ophyiulus pilosus (Newport, 1842) & Oph pil. & 2.8 & 42 & 15 \\
\hline Polydesmus complanatus (Linnaeus, 1761) & Po_com. & 10.5 & 379 & 36 \\
\hline Polydesmus denticulatus C.L.Koch, 1847 & Po_den. & 3.0 & 3 & 1 \\
\hline Polyzonium germanicum Brandt, 1831 & Py_germ. & 1.6 & 8 & 5 \\
\hline Tachypodoiulus niger (Leach, 1815) & Ta_nig. & 5.3 & 179 & 34 \\
\hline \multicolumn{5}{|l|}{ Isopoda } \\
\hline Protracheoniscus politus (C.Koch, 1841) & Pr_poli. & 38.3 & 1,110 & 29 \\
\hline Hyloniscus riparius (C.Koch, 1838) & H_rip. & 21.2 & 170 & 8 \\
\hline Lepidoniscus minutus (C.Koch, 1838) & L_min. & 1.0 & 1 & 1 \\
\hline Ligidium germanicum Verhoeff, 1901 & Lìger. & 1.0 & 1 & 1 \\
\hline Ligidium hypnorum (Cuvier, 1792) & Li_hyp. & 12.7 & 51 & 4 \\
\hline Oniscus asellus Linnaeus, 1758 & O_asell. & 1.0 & 1 & 1 \\
\hline Trachelipus ratzeburgii (Brandt, 1833) & T_ratb. & 9.6 & 163 & 17 \\
\hline Porcellio scaber Latreille, 1804 & Pe_scab. & 2.0 & 6 & 3 \\
\hline
\end{tabular}

weighted (Ter Braak \& Šmilauer 2002, Lepš \& Šmilauer 2003).

To assess the significance of the association of different invertebrates with soil skeleton, the study localities were divided into two groups. The first group consisted of locations with high skeleton contetnt ( $>40 \%$, Ske. H.) and the second group of sites with low skeleton content $(<40 \%$, Ske. L.). Based on the results of DCA and RDA the relationships between the two groups of the skeleton content and the occurrence of individual species were compared. 

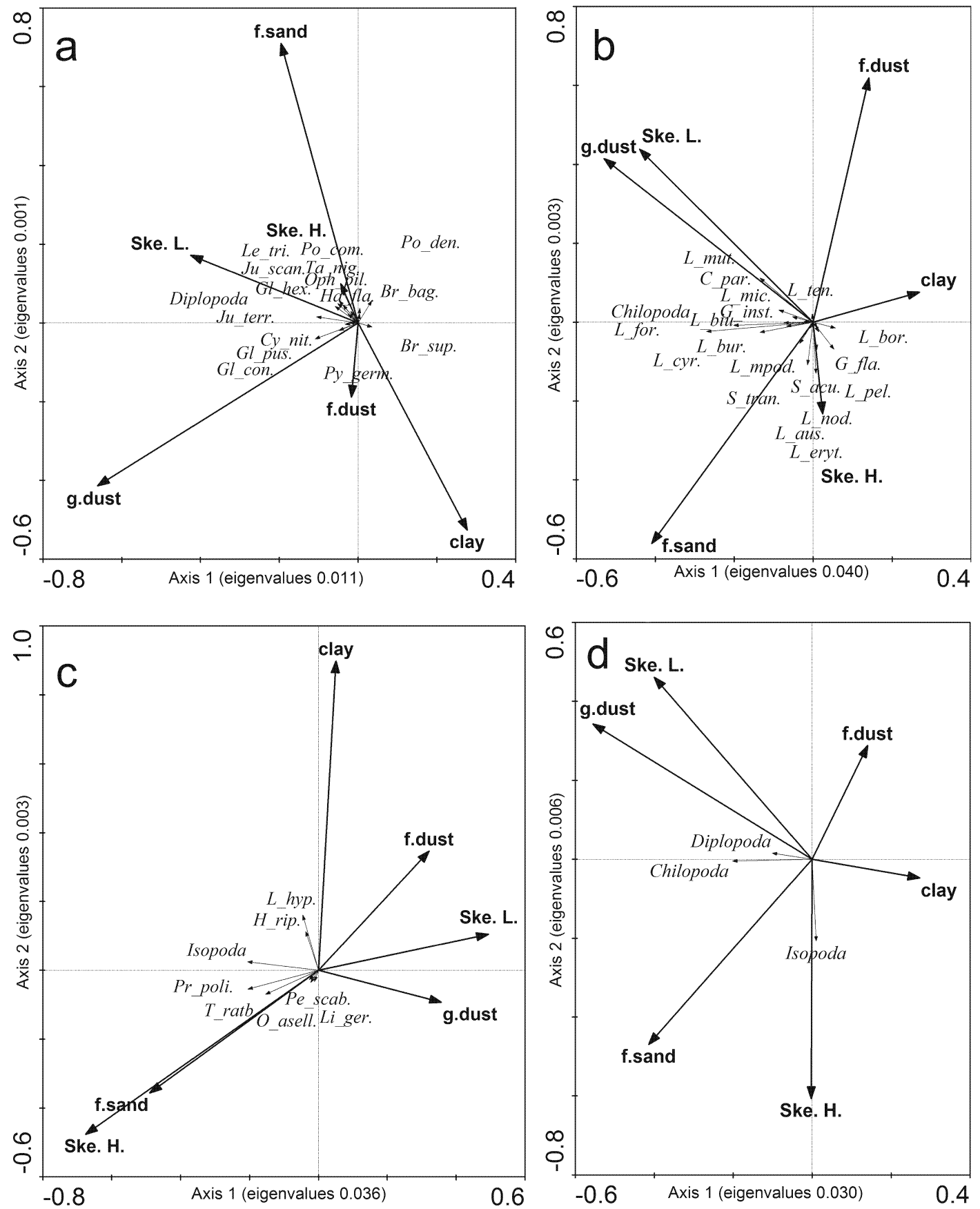

Fig. 2. Results of redundancy analysis ordination of invertebrate assemblages with the environmental skeleton content and particle size of soil - a. Millipedes. - b. Centipedes. - c. Terrestrial isopods. - d. All species of each group combined. Abbreviations: Ske. $\mathrm{H}$ - skeleton high, Ske. L - skeleton low, f.dust - fine dust, g.dust - gross dust, f.sand - fine sand. For abbreviations of species, see Table 2.

CCA was used to find the links between the occurrence of individual soil arthropod species and each of the following environmental vari- ables: soil moisture, soil reaction and chemical properties. For soil reaction, the input data were split into two categories: $\mathrm{pH}-\mathrm{kat} \mathrm{A}$ (soil reaction 
with a value of $<3.5 \mathrm{pH} / \mathrm{KCl}$ - a very strongly acidic soil reaction) and $\mathrm{pH}-\mathrm{katB}$ (soil reaction with a value of $>3.5 \mathrm{pH} / \mathrm{KCl}$ - a strongly acidic soil reaction), while the highest measured $\mathrm{pH}$ reached 5.1 (acidic). The input data of chemical properties were divided into three groups (exchangeable, accessible, bound elements).

The level of significance was set at $p<0.05$ for all testing procedures. Statistical analyses were performed by the STATISTICA Cz software, version 9.2 (StatSoft, Inc.).

\section{Results}

Overall information on the soil properties and numbers of specimens of different species trapped in the 38 study sites is provided in Table1 and 2 , respectively.

\subsection{Skeleton content and particle size}

At 16 sites, soil skeleton content and particle size were classified to be the major site-specific factors, meaning that large stones (boulders) were represented throughout the soil profile, the range being $44.0 \%$ to $64.9 \%$ (for the 16 sites, mean \pm S.D.: $52.3 \% \pm 5.8 \%$ ). In these sites, individual boulders protruding above the soil surface formed barriers for growth of herbaceous vegetation. The sites were also generally lacking undergrowth, at best, moss and lichen communities were found on the boulders.

In these sites, mainly terrestrial isopods occurred, representing $97.9 \%$ of the dominant species; Trachelipus ratzeburgii and Protracheoniscus politus demonstrate this finding (Fig. 2c). In contrast, the isopods Ligidium hypnorum and $H$. riparius showed a positive relationship to the soils with low skeleton content, colonising particularly soils with high content of clay particles. Porcellio scaber and Oniscus asellus were indifferent in relation to these environmental factors (Fig. 2c).

Millipedes had a positive correlation with the factor of lower presence of skeleton and particle size in the $0.01-0.05 \mathrm{~mm}$ fraction (gross dust), where axis 1 represents $90.4 \%$ and axis 2 represents $97.9 \%$ of all cases of occurrence of milli- pedes (Fig. 2a). The species Glomeris connexa, Glomeris pustulata and Cylindroiulus nitidus were positively correlated to the particle size fraction 0.01-0.05 $\mathrm{mm}$ (gross dust) (Fig. 2a). In contrast, a portion of the species, dominated by Leptoiulus trilobatus and Polydesmus complanatus, showed a positive relationship to the sites with a higher share of skeleton and the particle size fraction of $0.05-2 \mathrm{~mm}$ (fine sand).

Chilopods showed a significant correlation with the factors of coarse dust and fine sand, and accordingly, their vector forms an acute angle with the skeleton low vector (Fig. 2b, d). From this we can conclude that centipedes were more abundant in the locations with lower content of the skeleton. The individual species are dispersed between the Skeleton Low and Skeleton High vector, of which Lithobius mutabilis has a positive relationship to the sites with low skeleton content, while $L$. erythrocephalus has a positive relationship to the sites with a higher content of skeleton (Fig. 2b).

\subsection{Moisture}

The sites were divided into two groups of which the one comprising sites with lower volumetric moisture was found to be predominant, while the other one consisted of three heavily waterlogged sites (No. 19, 20 and 23, Table 1B).

Situated in flat terrain and being the richest in terms of moisture, the site No. 23 showed an average volumetric moisture (Table 1B) and low incidence of soil arthropod fauna (415 individuals). At this site, millipedes featured sporadic representation in terms of both species and numbers (27 ind.), with $P$. complanatus accounting for a half of them (13 ind.). The highest species diversity occurred in centipedes (16 species), which was represented by nine species. Of these, $L$. mutabilis (42\%) and Lithobius forficatus (19\%) prevailed. The relict species, Lithobius biunguiculatus, was represented by one individual. The largest numbers were those of Isopoda (279 ind.) that were represented by only three species, $H$. riparius $(54 \%)$, P. politus $(30 \%)$ and L. hypno$\operatorname{rum}(16 \%)$.

Another site (No. 20), a peat bog, had also a notable and permanent groundwater level. It was 

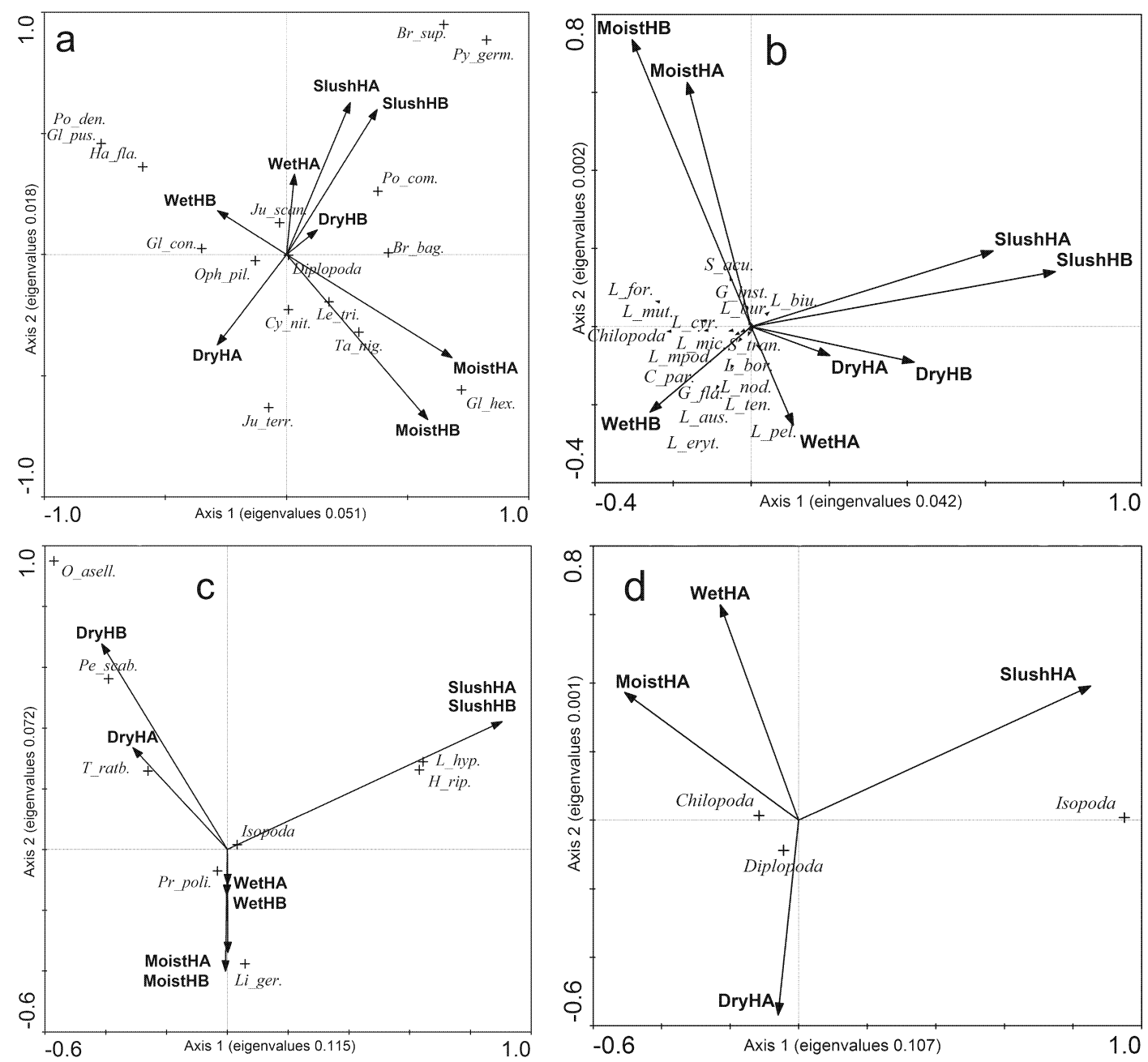

Fig. 3. Results of canonical correspondence analysis ordination of invertebrate assemblages with soil moisture.a. Millipedes. - b. Centipedes. - c. Terrestrial isopods. - d. All species of each group combined. Abbreviations: DryHA - dry soil in horizon A, DryHB - dry soil in horizon B, WetHA - wet soil in horizon A, WetHB - wet soil in horizon $B$, MoistHA - moisture soil in horizon A, MoistHB - moisture soil in horizon B, SlushHA - slush soil in horizon A, SlushHB - slush soil in horizon B. For abbreviations of species, see Table 2.

characterised by consistency of the average value of volumetric soil moisture in both upper $(48.05 \pm$ $1.01 \%)$ and lower $(49.34 \pm 0.56 \%)$ soil layer and, just like the site No. 23 above, a low occurrence of soil arthropods (45 ind.). Millipedes were represented only by $P$. complanatus ( 5 ind.) and centipedes by six species: L. mutabilis (25 ind.), $L$. erythrocephalus (6 ind.), Lithobius cyrtopus (3 ind.), Lithobius tenebrosus (3 ind.), L. forficatus (3 ind.) and L. microps (1 ind.). Terrestrial isopods absented here.

In the third site (No. 19) influenced by water, the average volumetric moisture reached $42.53 \pm$ $2.45 \%$ in the upper and $49.41 \pm 0.21 \%$ in the lower layer of the soil, with occasional drop of the groundwater level during the summer. The latter fact was not reflected in rising abundance of individual species compared with the above-mentioned sites more strongly influenced by water. The population of millipedes was very low (13 ind.): L. trilobatus $(15 \%)$, P. complanatus $(62 \%)$ and Tachypodoiulus niger (23\%). Centipedes were more numerous (74 ind.): L. mutabilis (49\%), L. erythrocephalus (39\%), L. forficatus 

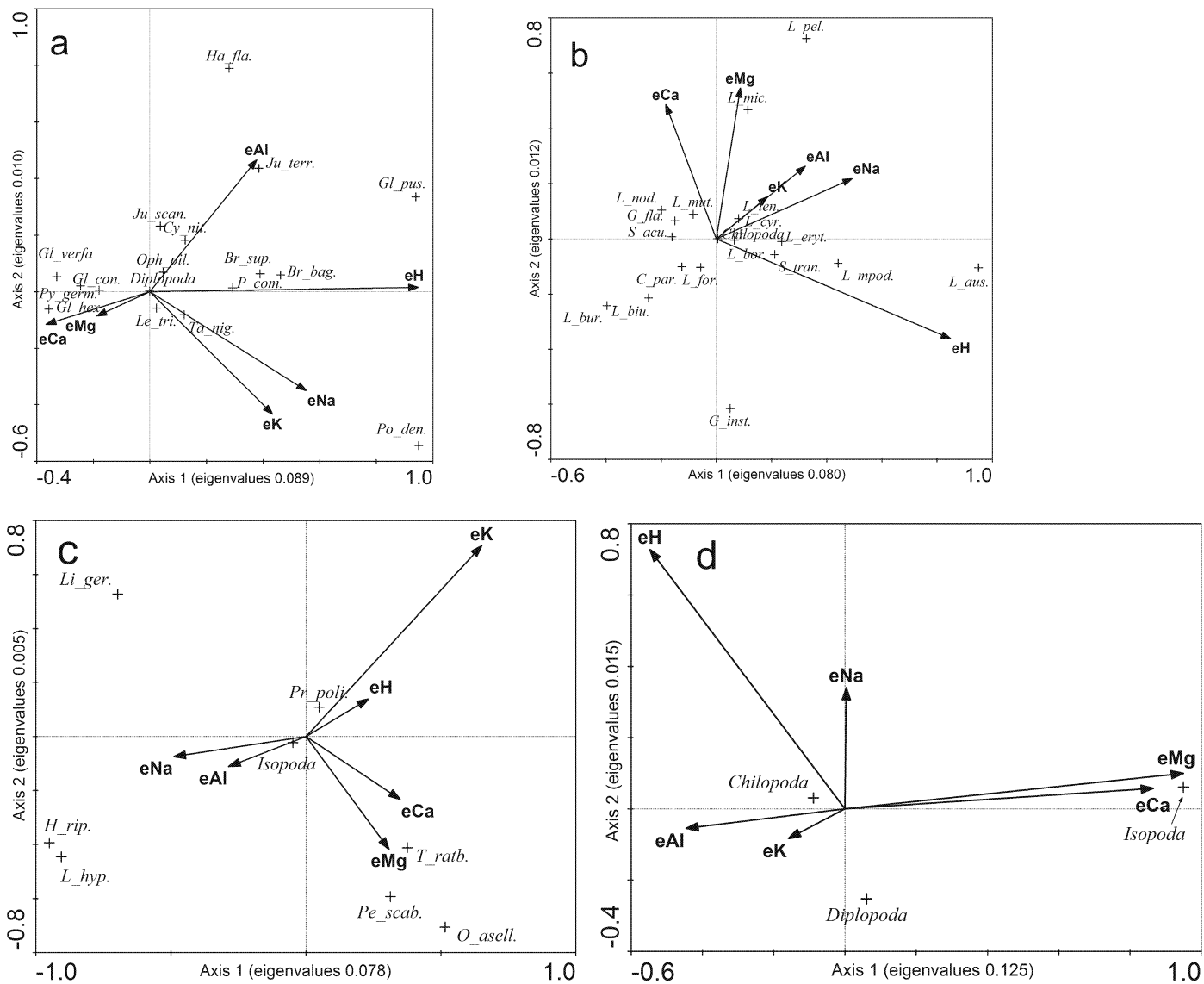

Fig. 4. Results of canonical correspondence analysis ordination of invertebrate assemblages with exchangeable macroelements in soil. - a. Millipedes. - b. Centipedes. - c. Terrestrial isopods. - d. All species of each group combined. For abbreviations of species, see Table 2.

(3\%), L. cyrtopus (3\%), L. tenebrosus (1\%) and S. acuminata $(1 \%)$.

For Chilopoda, CCA analysis was applied. The chilopod vector passes between those of of moist soil (MoistHA, MoistHB) and wet soil (WetHA, WetHB) with a slight tendency to the wet soil (Fig. 3d). This means that centipedes were associated with sites of moist soil. Between the WetHA and WetHB vectors, there is a noticeable difference in moisture, which is related to the difference in the skeleton content in the soil.

Lithobius erythrocephalus and L. austriacus (Fig. 3b) are different from the rest of the centipede species due to their association with increased soil moisture in the lower layers and lower moisture content in the top part of the soil. Strigamia acuminata is a species that almost follows the gradient vector of moist soil (MoistHB) with higher content of soil moisture in the lower layers, confirming its ecological niche. Lithobius biunguiculatus suggests to some extent a bond to the sites with strong waterlogging and groundwater level projecting as far as the upper layers of soil throughout the year. The vector of dry soil (DryHA, DryHB) lacked any species, which confirms the necessity of soil moisture for the success of centipede representatives in forest soil.

The individual millipede species are so adaptable that they clustered into the centre of all the gradient vectors of CCA, making determination of any precise correlations impossible. However, some tendencies are worth of mentioning. Cylindroiulus nitidus and Ophyiulus pilosus (Fig. 3a) are species tending towards the vector of dry soil (DryHA), while L. trilobatus, Julus terrestris and Tachypodoiulus niger rather showed associa- 
tions with the vector of moist soil in the lower layers (MoistHB). Glomeris hexasticha and $\mathrm{Bra}$ chyiulus bagnalli had a positive relationship with moisture in the upper soil layers (Moist HA). Species recorded at wet sites (WetHB), where primarily the lower layer of soil was moist, involved Julus scandinavius, G. connexa, G. pustulata, Haasea flavescens and Polydesmus denticulatus. Slush sites (WetHA) with water often rising up to the ground level, were colonised by Brachydesmus superus and Polyzonium germanicum (Fig. 3a).

For the community of terrestrial isopods, only a weak correlation in CCA with the gradient axis of slush soil (SlushHA, SlushHB) was detected when taking into account all the species. Ligidium hypnorum and $H$. riparius showed positive correlation with slush soils. In contrast, P. scaber and $O$. asellus occurred in dry areas (DryHB), where drying was extending as far as the lower soil layer (Fig. 3c). Porcellio scaber (6 ind.) and O. asellus ( 1 ind.) were captured at the site no. 29 , which is a dry habitat. Trachelipus ratzeburgii occurred most frequently at the sites where soil moisture in the upper layers was low (DryHA). Protracheoniscus politus and Ligidium germanicum were recorded on the wet sites (WetHA, WetHB) with values of soil moisture very similar to those measured at the moist sites (MoistHA, MoistHB).

\subsection{Soil reaction}

Soil reaction was determined in all the horizons of the soil profile down to the parent rock level. The study sites had very low $\mathrm{pH}$, fully equalling that of sites in mountainous/sub-mountainous spruce stands (Table $1 \mathrm{~A}$ ). The average $\mathrm{pH} / \mathrm{KCl}$ value reached $3.29 \pm 0.46$ ( $\min .2 .48$ at site No. 1, max. 5.01 at site No. 20). As regards soil reaction and the presence of individual species, CCA confirmed that there were no statistically significant relationships of the studied invertebrate species with the range of the observed soil $\mathrm{pH}$ values (results not shown). With generally no relationship of chilopods to soil $\mathrm{pH}$ in this study, we even found a tendency to a positive one with Lithobius burzenlandicus and Ligidium germanicum, while other studies have found, if any, negative rela- tionship of chilopods with soil $\mathrm{pH}$ (Blackburn et al. 2002, Jabin 2008).

\subsection{Macroelements in soil}

Soil analysis determined the contents of individual elements and their oxides that are usually important with respect to flora, while their relationships with fauna are not generally defined. Since mostly a negative relationship with the content of individual elements in the soil was determined for centipedes, millipedes and terrestrial isopods, which was manifested in a regular distribution of the individual species with respect to all the elements monitored, each species was evaluated separately for its relationship to macroelements in soil.

Lithobius pelidnus indicated a strong bond to calcium and magnesium, both the exchangeable (eCa, eMg, Fig. 4b) and accessible (paCa, paMg, Fig. 5b) form. The relationship with $\mathrm{Mg}$ was even more distinct in L. microps, which followed the gradient vector of soil magnesium $(\mathrm{Mg})$ in both its accessible and exchangeable form (Figs. 4b, $5 b)$. A positive correlation appeared also for $\mathrm{Ca}$ and $\mathrm{Mg}$ in five other species of Chilopoda ( $S$. acuminata, Geophilus flavus, L. biunguiculatus, $L$. nodulipes and L. tenebrosus), in four species of Diplopoda (G. hexasticha, G. pustulata, J. terrestris and $P$. germanicum), and in three species of Isopoda ( $O$. asellus, $P$. scaber and $T$. ratzeburgii). Interestingly, along with the change in the forms (exchangeable, accessible, bound) of oxides of $\mathrm{Ca}$ and $\mathrm{Mg}$, there was no change of the species relationships with those elements. The chilopods Cryptops parisi and G. flavus, colonising deeper soil layers, exhibited a correlation with the content of bound iron (tFe) (Fig. 6b), which, due to strongly acidic $\mathrm{pH}$, occurred in substantial quantities (site No. $14 ; 39,000 \mathrm{mg} \times \mathrm{kg}^{-1}$ of Fe oxide). Lithobius cyrtopus, $L$. erythrocephalus, $L$. austriacus and Lithobius borealis correlated with the increased content of accessible, oxidised phosphorus (paP) in the soil (Fig. 5b).

Although most of the millipede species showed a negative association to all the elements monitored, $P$. denticulatus had a strong positive association to accessible potassium (paK, Fig. 5a) and exchangeable sodium (eNa, Fig. 4a). Julus terrestris and $H$. flavescens occurred in the soils 

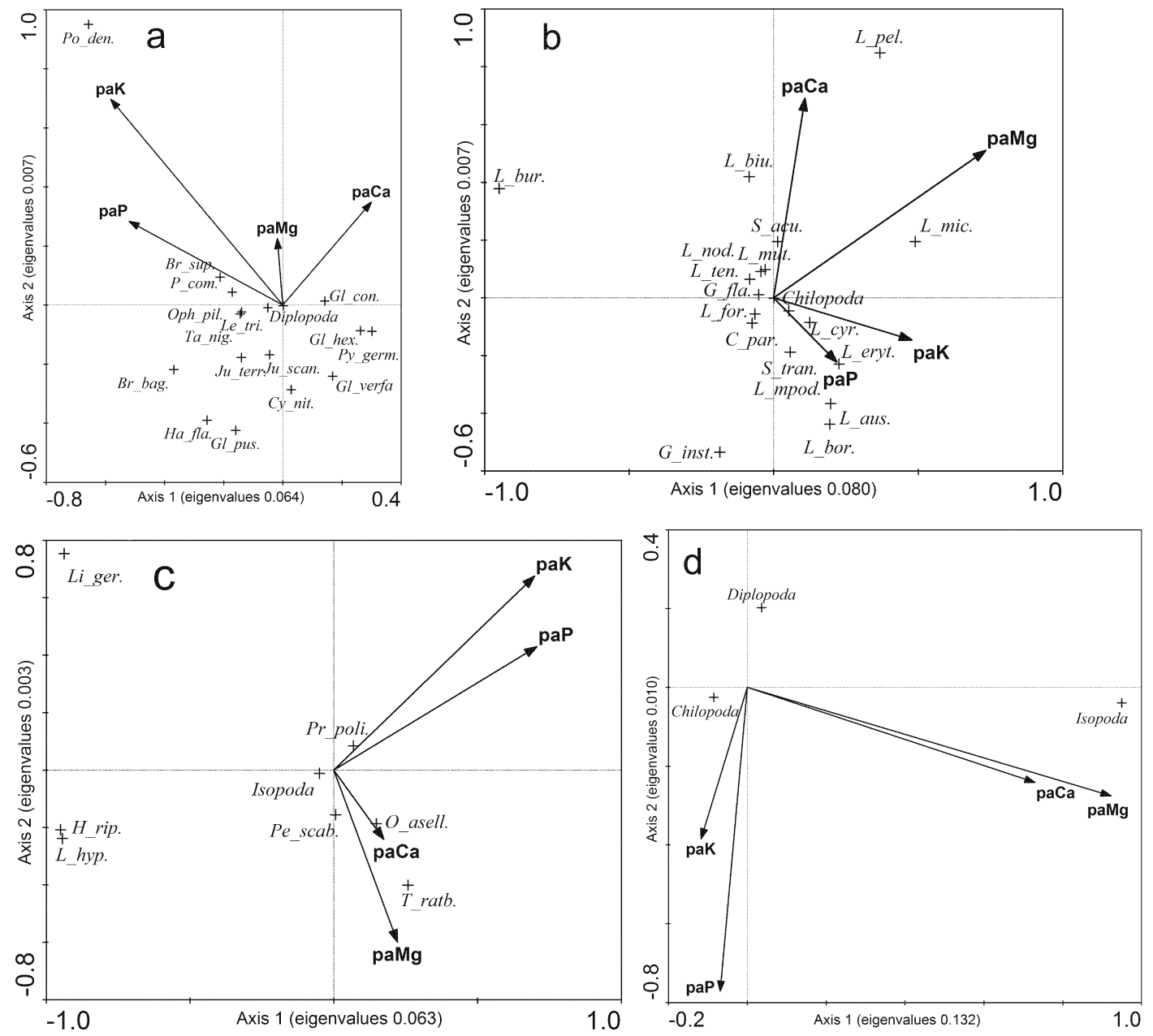

Fig. 5. Results of canonical correspondence analysis ordination of invertebrate assemblages with accessible macroelements in soil. - a. Millipedes. - b. Centipedes. - c. Terrestrial isopods. - d. All species of each group combined. For abbreviations of species, see Table 2.

with increased content of exchangeable aluminium (eAl) (Fig. 4a), indicating soils with high contents of clay particles and acidic soil reaction. The species such as $G$. connexa, $G$. hexasticha and $P$. germanicum were found in soils with increased content of exchangeable calcium and magnesium (eCa, eMg) (Fig. 4a), with the maximum contents of exchangeable calcium and magnesium being recorded at the sites No. $20(50.66$ $\left.\mathrm{cmol}^{+} \times \mathrm{kg}^{-1}\right)$ and No. $1\left(14.71 \mathrm{cmol}^{+} \times \mathrm{kg}^{-1}\right)$, respectively.

Terrestrial isopods were slightly negative in their relation to the content of potassium, magnesium and calcium in all forms, but they showed more frequent associations with heavy soils of acidic reaction and increased content of aluminium (eAl). Ligidium hypnorum and $H$. riparius were significantly associated with the content of both exchangeable (eAl, Fig. 4c) and bound aluminium (tAl, Fig. $6 \mathrm{c}$ ). The most frequently occurring isopod species, $P$. politus, had a positive relationship with the soils rich in potassium in all forms ( $\mathrm{eK}, \mathrm{paK}, \mathrm{tK})$, indicated by the fact that the vector spacing distance to the vector (K) was balanced in all forms of the element (Figs. 4c, 5c, 6c). The sites with a high content of calcium and magnesium supported $T$. ratzeburgii, $P$. scaber and $O$. asellus. They occurred mostly in the presence of exchangeable calcium and magnesium (eCa, eMg, Fig. 4c) which are 

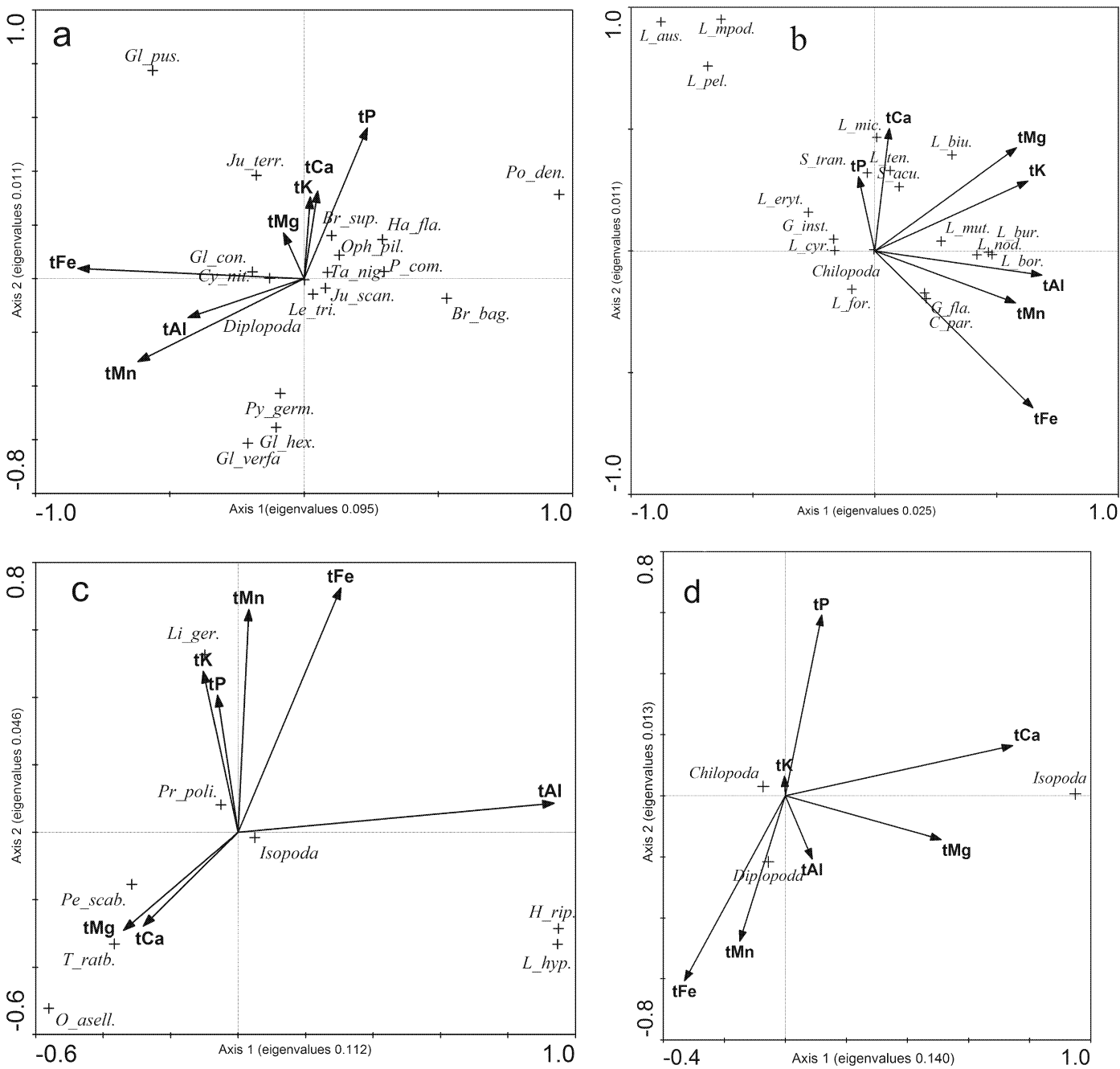

Fig. 6. Results of canonical correspondence analysis ordination of invertebrate assemblages with bound macroelements in soil. - a. Millipedes. - b. Centipedes. - c. Terrestrial isopods. - d. All species of each group combined. For abbreviations of species, see Table 2.

part of the soil solution on the surface of colloids and immediately affect the habitat of organisms. In contrast, $L$. hypnorum had a negative association to the presence of both accessible and exchangeable calcium and magnesium (eCa, paCa, eMg, paMg, Figs. 4c, 5c) and was indistinctively positive in its relation to bound potassium (tK, Fig. 6c).

\section{Discussion}

Soil environment as the basis for an ecosystem has not been comprehensively analysed in terms of the relationships between pedological characteristics and epigeic fauna (Schaefer \& Schauermann 1990, Scheu \& Poser 1996, Blackburn et al. 2002, Scheu \& Setälä 2002, Jabin 2008). The relationship between the amount of organic matter and the $\mathrm{pH}$ of soil is variable (Salamon et al. 2008, Fierer et al. 2009) and influences the biomass of fungi and bacteria, and thus the food supply for the consumer level. It has been shown that Lithobiomorpha (Lithobius crassipes L. Koch 1862, L. mutabilis), according to the content of fatty acids, are consumers of fungi and also hunters of springtails and oribatid mites feeding on fungi (Maraun et al. 2003, Chahartaghi et al. 
2005, Maraun et al. 2011, Ferlian et al. 2012). The members of Geophilomorpha (S. acuminata, Geophilus ribauti Brölemann, 1908) prefer bacteria eaters (Ferlian et al. 2012).

In order to shed light on relationships between the soil environment and representatives of Chilopoda, Diplopoda and Isopoda, a detailed account of soil variables and abundance of the above mentioned invertebrates was undertaken in this study in the area of the mountains of Moravian-Silesian Beskyds. Among the major factors of soil environment for centipedes, millipedes and terrestrial isopods are the nutritional components of soil-forming processes, soil moisture, $\mathrm{pH}$, the level of skeleton content as well as the height of accumulated humus, and soil air content, of which the two latter ones were not included in this study.

\subsection{Skeleton content and particle size}

Centipedes have been recorded in corridors formed by members of Lumbricidae or those left by rotted roots of trees (Albert 1982). Jabin (2008) mentioned the direct influence of airspace in soil on the presence of epigeic Lithobiomorpha and Geophilomorpha. However, soil skeleton content and particle size have not been studied to the extent that would allow us to link gained knowledge to the occurrences of the individual soil arthropod species. These factors, however, are significant for changes in soil moisture, air capacity, soil fertility and associated soil chemistry, which is related to the content of colloidal solutions. In this study, centipedes, millipedes and terrestrial isopods were associated with the sites with increased skeleton content and they were less abundant on soils with high content of clay (Fig. 2d). Centipedes do not colonise clayey soils with reduced interstitial air volume (Attems 1926, Albert 1982). Therefore, it is assumed that soil aeration is an important factor influencing the presence of centipedes, millipedes and terrestrial isopods in the soil profile. Porcellio scaber and $O$. asellus were indifferent in their relation to skeleton content and particle size (Fig. 2c), which could be due to the low representation of these species. Therefore, it was not possible to establish any indisputable relationships with the individual environmental factors. The finest soil particles, clay, had no connection with the occurrence of species, which means that centipedes, millipedes and isopods prefer places with aerated soil profile. However, information on underground species would be required.

\subsection{Moisture}

Moisture is an important soil property for the distribution of epigeic fauna. For example, Schlaghamerský et al. (2014) found the greatest species diversity of centipedes, millipedes and isopods, in wet sites on the bottom of ravines, i.e. in the places offering favourable conditions in winter in addition to other seasons. In accordance, since the mountains of Moravian-Silesian Beskyds are characterised by high precipitation (average annual total of $>1,200 \mathrm{~mm}$ ), there were no sites with a dry soil profile, which contributed to the wide range of the species caught. Myriapoda are among the organisms particularly sensitive to drying (Curry 1974, Lewis 1981) due to the weak epicuticular wax layer on the epidermis (Blower 1951, Mead-Briggs 1956). Albert (1983) mentions preference of moist habitats by myriapods with close to $100 \%$ relative humidity, with Lithobiomorpha preferring relative humidity above $96 \%$ (Fründ 1987). They are able to find even a very small soil niche with increased moisture (Weil 1958). Centipedes occur abundantly on wet soil surface and increase activity in the rain (Zapparoli 1997). However, they are not always able to survive periods of flooding (Zerm 1997). According to Cloudsley-Thompson and Crawford (1970), there is no evidence of centipedes taking up moisture from saturated air.

Overall, centipedes preferred freshly moist sites (Moist HA, Fig. 3d) with the volumetric moisture of the soil never decreasing below $25 \%$. The increased presence of Lithobiomorpha and Geophilomorpha in moist habitats is related to the availability of food, because in moist habitats, molds are more abundant than bacteria due their better moist resistance (Bardgett et al. 2005, Gordon et al. 2008). According to Jabin (2008), S. acuminata, L. mutabilis and L. forficatus show a greater drought resistance compared to smaller centipedes, such as L. microps or L. austriacus. 
Brachydesmus superus, $P$. germanicum and $G$. connexa were the diplopod species colonising sites with waterlogged soil (Fig. 3a). Cylindroiulus nitidus and $O$. pilosus appeared to be quite resistant to drying (Fig. 3a). These species were found on drying soils as well as on the others, because some species are more drought resistant than other ones. However, it is not clear how some species can survive periods of short-term drought in the course of the growing season.

Terrestrial isopods require moist soil, too (Vasconcellos et al. 2013). Accordingly, increased numbers of members of this group on agricultural, all-year-round irrigated soils, were confirmed by Morón-Rios et al. (2010). In this study, association to wet soils was found in two other species, $L$. hypnorum and $H$. riparius that were closely bound to waterlogged soils (Fig. $3 c)$.

\subsection{Soil reaction $(\mathrm{pH})$}

As regards soil reaction, there was no significant differentiation in respect to the study sites in the studied species spectrum of Diplopoda, Chilopoda and terrestrial Isopoda in this study. Similar conclusion for chilopods was reached by Jabin (2008). In general, information on soil arthropods in relation to soil reaction is not sufficient. However, Blackburn et al. (2002) found a strong link of the chilopod Brachygeophilus truncorum (Bergsoë \& Meinert, 1886) to acidic soils. This is due to the availability of food, i.e. fungi are more abundant in an acid medium than bacteria (Francis 1986).

In the study by Scheu and Poser (1996), soil $\mathrm{pH}$ affected the macrofauna near tree trunks, with the importance of $\mathrm{pH}$ decreasing with increasing distance from the trunks. Increased acidity was preferred by the centipede $S$. acuminata, while the abundance of $G$. insculptus was reduced in the same setting (Scheu \& Poser 1996). In another study, the millipede Mycogona germanica (Verhoeff, 1892) colonised an acidic environment (Ellenberg et al. 1986). In our study, the habitat conditions were mainly acidic $(\mathrm{pH} / \mathrm{KCl}$ 2.74 to 5.01), providing suitable environment for a wide range of centipedes, millipedes and terrestrial isopods.

\subsection{Soil chemistry}

Soil chemistry affects soil-forming processes and, indirectly, the quality of soil as a source of food for soil fauna through the development of microbial activity (Wardle 1992, Blackburn et al. 2002).

Scheu and Schaefer (1998) found high contents of phosphorus, nitrogen and carbon to be the limiting factors for soil microorganisms. Increased acidification reduces the diversity and generally increases the abundance of mesofauna in forest soils through high representation of some of the dominant species (Hågvar \& Kjøndal 1981, Hågvar 1984, Baas \& Kuiper 1989).

The results of the present study indicate preference of sites with increased levels of calcium and magnesium in centipedes, particularly $L$. pelidnus and L. biunguiculatus and in the terrestrial isopods $T$. ratzeburgii and $O$. asellus, in contrast to millipedes. This may be related to the finding that increased calcium and magnesium contents have a favourable influence on the occurrence of arthropods with calcium-based exoskeletons (Hopkin \& Read 1992, Jabin 2008).

The availability of nutrients can be a limiting factor. Millipedes were found to respond negatively to accessible $\mathrm{Ca}$ and $\mathrm{Mg}$ (Fig. 5d) in the proton forms, which are better accessible for plants than their exchangeable, oxidized forms. Centipedes showed no associations to the level of individual elements, except for $S$. acuminata and L. microps, the species with a positive link to the presence of $\mathrm{Ca}$ and $\mathrm{Mg}$ (Figs. 4b, 5b, 6b). In terrestrial isopods, the response was clear with $T$. ratzeburgii, $O$. asellus and $P$. scaber having positive responses to increased content of $\mathrm{Ca}$ and $\mathrm{Mg}$ in all forms (Figs. 4c, 5c, 6c). Ligidium hypnorum and $H$. riparius confirmed the relationship to heavy soils through their bond to $\mathrm{Al}$ and $\mathrm{Na}$ (Figs. 4c, 6c). Protracheoniscus politus preferred the sites with increased levels of $\mathrm{K}$ in all forms (Figs. $4 c, 5 c, 6 c)$.

\section{Conclusion}

The study indicated how millipedes, centipedes and terrestrial isopods are affected by selected soil characteristics. Soil skeleton content and par- 
ticle size were indicated as important factors. The sites with the most boulders on the soil surface have a favourable hydric regime of soil associated with high representation of centipedes and terrestrial isopods. Species like L. austriacus, $L$. erythrocephalus and $L$. nodulipes occurred specifically in areas with increased content of boulders. Of these, L. nodulipes reached increased incidence especially in valleys where mountain streams expose boulders on the soil surface and where soil moisture regimes are good. Influence of soil reaction $(\mathrm{pH} / \mathrm{KCl}$ ) did not show a significant trend. The most marked response to nutrient levels was shown in isopods $T$. ratzeburgii, $O$. asellus and $P$. scaber, i.e. in species with a tendency to seek increased content of $\mathrm{Ca}$ and $\mathrm{Mg}$. The isopods $L$. hypnorum and $H$. riparius were associated to heavy soils with high levels of Al. In contrast, the chemical composition of soil did not show a significant link to the occurrence of centipedes and millipedes in the soil environment.

General understanding of the ecological demands of individual centipede, millipede and terrestrial isopod species is insufficient, although with their living habits, they form an important part of nutrient cycling in the ecosystem. Such lack of general knowledge disallows any deeper confrontation of the results of this study with those of other studies.

Acknowledgements. This study was supported by the Ministry of Education of the Czech Republic (VZ MSM 6215648902) and Mendel University in Brno, and by the Netex Ltd., Děčín, Nadace ČEZ Co. in Prague, Lafarge Cement Co. in Člžzovice.

\section{References}

Albert, A. M. 1982: Species spectrum and dispersion patterns of chilopods on three Solling habitats. - Pedogiologia 23: 335-345.

Albert, A. M. 1983: Characteristics of two populations of Lithobiidae (Chilopoda) determined in the laboratory and their relevance with regard to their ecological role as predators. - Zoologischer Anzeiger 34: 214-226.

Attems, C. 1926: Myriapoda: 1-6. - In: Kükentbal, W. (Ed.), Handbuch der Zoologie. Berlin, Leipzig, Vierter Band, Erste Hälfte. 892 pp.

Baas, R. \& Kuiper, D. 1989: Effects of VAM infection and phosphate on Plantago major ssp. pleiosperma in relation to internal cytokinin concentrations. - Physiologia Plantarum 76: 211-215.
Bardgett, R. D., Yeates, G. W. \& Anderson, J. M. 2005: Patterns and determinants of soilbiological diversity: 100-118. - In: Bardgett, R. D., Usher, M. B. \& Hopkins, D. W. (eds), Biological Diversity and Function in Soils. Cambridge University Press, Cambridge. 411 pp.

Bedrna, Z. 1977: Pôdotvorné procesy a pôdne režimy [Soilforming processeses and soil regimes]. — Veda, SAV, Bratislava, 132 pp. [In Slovak.]

Blackburn, J., Farrow, M. \& Wallace, A. 2002: Factors influencing the distribution, abundance and diversity of geophilomorph and lithobiomorph centipedes. Journal of Zoology 256: 221-232.

Blower, J. G. 1951: A comparative study of the chilopod and diplopod cuticle. - Quarterly Journal of Microscopical Science 92: 142-161.

Brady, N. C. \& Weil, R. R. 2008: The nature and properties of soil. 14th edition. - Pearson Prentice Hall, Upper Saddle River, New Jersey, Columbus, Ohio. 990 pp.

Briones, M. J. I., Ineson, P. \& Piearce, T. G. 1997: Effects of climate change on soil fauna; responses of enchytraeids, Diptera larvae and tardigrades in a transplant experiment. - Applied Soil Ecology 6: 117-134.

Casagrande, A. 1948: Classification and identification of soils. - Transactions of the American Society of Civil Engineers 113: 901-930.

Carpenter, D., Hammond, M. P., Sherlock, E., Lidgett, A., Leigh, K. \& Eggleton, P. 2012: Biodiversity of soil macrofauna in the New Forest: a benchmark study across a national park landscape. - Biodiversity and Conservation 21: 3385-3410.

Chahartaghi, M., Langel, R., Scheu, S. \& Ruess, L. 2005: Feeding guilds in Collembola based on nitrogen stable isotope ratios. - Soil Biology \& Biochemistry 37: 1718-1725.

Cloudsley-Thompson, J. L. \& Crawford, C. S. 1970: Water and temperature relations, and diurnal rhythms of scolopendromorph centipedes. - Entomologia Experimentalis et Applicata 13: 187-193.

ČSN ISO 11260/1998: Kvalita půdy - Stanovení kationtové výměnné kapacity při $\mathrm{pH}$ půdy a výměnných kationti̊ za použití roztoku chloridu barnatého [Soil quality - Determination of effective cation exchange capacity and base saturation level using barium chloride solution.] - 20 pp. [In Czech.] 1998 The International Standard ISO 11260 has the status of a Czech Standard.

ČSN ISO 11464/1998: Kvalita půdy - Příprava vzorků pro fyzikálně-chemické rozbory. [Soil quality - Preparation of samples for physical and chemical analysis.] 16 pp. [in Czech.] 1998 The International Standard ISO 11464 has the status of a Czech Standard.

Curry, A. 1974: The spiracle structure and resistance to desiccation of centipedes. - Symposia of the Zoological Society London 32: 365-382.

Čurlík, J. \& Šurina, B. 1998: Handbook of field survey and mapping of soils. - Research Institute of soil fertility. Bratislava. 134 pp. [In Slovak.]

David, J. F. \& Handa, I. T. 2010: The ecology of sapropha- 
gous macroarthropods (millipedes, woodlice) in the context of global change. - Biological Reviews 85 : $881-895$.

Dollery, R., Hodkinson, I. D. \& Jónsdóttir, I. S. 2006: Impact of warming and timing of snow melt on soil microarthropod assemblages associated with Dryasdominated plant communties on Svalbard. - Ecography 29: 111-119.

Dunger, W. \& Voigtländer, K. 2009: Soil fauna (Lumbricidae, Collembola, Diplopoda and Chilopoda) as indicators of soil ecosubsystem development in post-mining sites of Eastern Germany - a review. - Soil Organisms 81: 1-51.

Ellenberg, H., Mayer, R. \& Schauermann, J. 1986: Ökosystemforschung - Ergebnisse des Sollingprojektes. - Ulmer, Stuttgart. 507 pp.

Ferlian, O., Scheu, S. \& Pollierer, M. M. 2012: Trophic interactions in centipedes (Chilopoda, Myriapoda) as indicated by fatty acid patterns: variations with life stage, forest age and season. - Soil Biology \& Biochemistry 52: $33-42$.

Fierer, N., Strickland, M. S., Liptzin, D., Bradford, M. A. \& Cleveland, C. C. 2009: Global patterns in belowground communities. - Ecology Letters 12: 12381249.

Francis, A. J. 1986: Acid rain effects on soil and aquatic microbial biomass. - Experientia 42: 455-465.

Fründ, H. C. 1987: Raumliche Verteilung und Koexistenz der Chilopoden in einem Buchen-Altbestand. - Pedobiologia 30: 19-29.

Gordon, H., Haygarth, P. M. \& Bardgett, R. D. 2008: Drying and rewetting effects on soil microbial community composition and nutrient leaching. - Soil Biology \& Biochemistry 40: 302-311.

Haacker, U. 1968: Deskriptive, experimentelle und vergleichende Untersuchungen zur Autökologie rheinmainischer Diplopoden. - Oecologia 1: 87-129.

Hågvar, S. \& Kjøndal, B. R. 1981: Effects of artificial rain on the microarthropod fauna in decomposing birch leaves. - Pedobiologia 22: 409-422.

Hågvar, S. 1984: Six common mite species (Acari) in Norwegian coniferous forest soils: Relations to vegetation types and soil characteristics. - Pedobiologia 27: 355-364.

Hopkin, S. P. \& Read, H. 1992: The biology of millipedes. Oxford University Press, Oxford, New York, Tokyo. 233 pp.

Jabin, M. 2008: Influence of environmental factors on the distribution pattern of centipedes (Chilopoda) and other soil arthropods in temperate deciduous forests. - Cuvillier Verlag, Göttingen, Univerzity of Cologne, Köln. 128 pp.

Jandák, J. 2003. Cvičení z půdoznalství. — Mendlova zemědelská a lesnická univerzita v Brně, 92 pp. [In Czech.]

Kula, E., Lazorík, M. \& Tuf, I. H. 2011: Contribution to the knowledge of centipedes and terrestrial isopods of the Moravian-Silesian Beskids. - Acta Musei Beskidensis 3: $57-65$.

Kutílek, M. 1971: Ekologická klasifikace půdní vlhkosti
[Ecological classification of soil moistute]. — Vodní hospodářství 9: 250-256. [In Czech.]

Lepš, J. \& Šmilauer, P. 2003: Multivariate Analysis of Ecological Data Using CANOCO. - Cambridge University Press, London, 299 pp.

Lewis, J. G. E. 1981: The biology of centipedes. - Cambridge University Press, Cambridge, 476 pp.

Maraun, M., Martens, H., Migge, S., Theenhaus, A. \& Scheu, S. 2003: Adding to "the enigma of soil animal diversity": fungal feeders and saprophagous soil invertebrates prefer similar food substrates. - European Journal of Soil Biology 39: 85-95.

Maraun, M., Erdmann, G., Fischer, B. M., Pollierer, M. M., Norton, R. A., Schneider, K. \& Scheu, S. 2011: Stable isotopes revisited: Their use and limits for oribatid mites trophic ecology. - Soil Biology \& Biochemistry 43: 877-882.

Mařan, B. \& Káš, V. 1948: Biologie lesa I. Pedologie a mikrobiologie lesních půd [Forestry biology I. Pedology and microbiology of forest soils]. - Melantrich, Praha, 596 pp. [In Czech].

Mead-Briggs, A. R. 1956: The effect of temperature upon the permeability to water of arthropod cuticles. Journal of experimental Biology 33: 737-749.

Mehlich, A. 1984: Mehlich III Soil Test Extractant: A modification of Mehlich 2 Extractant. - Communications in Soil Science and Plant Analysis 15(12): 1409 1416.

Morón-Rios, A., Rodriguez, M. Á., Pérez-Camacho, L. \& Rebollo, S. 2010: Effects of seasonal grazing and precipitation regime on the soil macroinvertebrates of a Mediterranean old-field. - European Journal of Soil Biology 46: 91-96.

Němeček, J., Smolíková, L. \& Kutílek, M. 1990: Pedologie a paleopedologie [Soil science and paleopedology]. - Academia, Praha, 546 pp. [In Czech.]

Němeček, J., Macků, J., Vokoun, J., Vavříček, D. \& Novák, P. 2001: Taxonomický klasifikační system půd České republiky [Taxonomic classification system of soils of the Czech Republic]. - ČZU, Praha, 94 pp. [In Czech.]

Schaefer M. 1991: Secondary production and decomposition: 175-218, - In: Röhrig, E. \& Ulrich, B. (eds), Temperate Deciduous Forests. Ecosystems of the world 7. Elsevier. 635 pp.

Schaefer, M. \& Schauermann, J. 1990: The soil fauna of beech forests: comparison between a mull and a moder soil. - Pedobiologia 34: 299-314.

Scheu, S. \& Poser, G. 1996: The soil macrofauna (Diplopoda, Isopoda, Lumbricidae and Chilopoda) near tree trunks in a beech wood on limestone: indications for stemflow induced changes in community structure. Applied Soil Ecology 3: 115-125.

Scheu, S. \& Schaefer, M. 1998: Bottom-up of the soil macrofauna community in a beechwood on limestone: manipulation of food resources. - Ecology 79: 1573 1585.

Scheu, S. \& Schulz, E. 1996: Secondary succession, soil formation and development of a diverse community of 
oribatids and saprophagous soil macro-invertebrates. - Biodiversity Conservation 5: 235-250.

Scheu, S. \& Setälä, H. 2002: Multitrophic interactions in decomposer food webs: 223-264. — In: Tscharntke, T. \& Hawkins, B. A. (eds), Multitrophic level interactions. Cambridge University Press, Cambridge. $274 \mathrm{pp}$.

Schlaghamerský, J., Devetter, M., Háněl, L., Tajovský, K., Starý, J., Tuf, I. H. \& Pižl, V. 2014: Soil fauna across Central European sandstone ravines with temperature inversion: From cool and shady to dry and hot places. - Applied Soil Ecology 83: 30-38.

Schreiner, A. \& Decker, P., Hannig, K., Schwerk, A. 2012: Millipede and centipede (Myriapoda: Diplopoda, Chilopoda) assemblages in secondary succesion: variance and abundance in Western German beech and coniferous forests as compared to fallow ground. - Web Ecology 12: 9-17.

Soukup, J., Fuchsová, K., Pospíšilová, N., Salát, L. \& Zeman, P. 1987: Vyšetřování zahradnických půd a substrátů. [Investigation horticultural soil and substrates]. - Aktuality Výzkumného a šlechtitelského ústavu okrasného zahradnictví v Průhonicích, 62 pp. [In Czech.]

Ter Braak, C. J. F. \& Smilauer, P. 2002: CANOCO Reference manual and CanoDraw for Windows Users guide: Software For Canonical Community Ordination verzion 4.5, (Ithaca, NY, USA), 500.

Tuf, I. H. \& Tufová, J. 2008: Proposal of ecological classification of centipede, millipede and terrestrial isopod faunas for evaluation of habitat quality in Czech Re- public. - Časopis Slezského Muzea Opava (A) 57: $37-44$

Vasconcellos, L. F. R., Segat, J. C., Bonfim, J. A., Baretta, D. \& Cardovo, J. B. N. 2013: Soil macrofauna as an indicator of soil quality in an undisturbed riparian forest and recovering sites of different ages. - European Journal of Soil Biology 58: 105-112.

Wardle, D. A. 1992: A comparative assessment of factors which influence microbial biomass carbon and nitrogen levels in soil. - Biological Review 67:321-358.

Weil, E. 1958: Zur Biologie der einheimischen Geophiliden. - Zeitschrift für angewandte Entomologie 42:173-209. [In German.]

Zapparoli, M. 1997: Urban development and insect biodiversity of the Rome area, Italy. — Landscape Urban Planning 38: 77-86.

Zbíral, J. 1997: Jednotné pracovní postupy, Ústřední kontrolní a zkušební ústav zemědělský [Standard operational procedures]. - Brno. Central Institute for Supervising and Testing in Agriculture. 199 pp. [In Czech.]

Zbíral, J. 2002: Analýza půd I. Jednotné pracovní postupy. [Soil analysis I. Integrated work procedures]. - Central Institute for Supervising and Testing in Agriculture, Brno, 28-54. [In Czech.]

Zerm, M. 1997: Die Fauna der Tausend-, Hundert- und Zwergfüsser (Myriapoda: Diplopoda, Chilopoda, Symphyla) sowie der Landasseln (Isopoda: Oniscidea) im Unteren Odertal, unter besonderer Berücksichtigung des Standortfaktors Überschwemmung. Zoologische Beiträge 38 (1): 97-134. [In German.] 